\title{
Monthly Active User Improvement in Social Media Mobile Phone Application: The Six Sigma Approach
}

\author{
Sulistia Fitriaty* \\ School of Business and Management, Institut Teknologi Bandung, Indonesia
}

\begin{abstract}
This research study is focused on one social media that starts as an instant messaging app called ABC. $A B C$ is an app originally from Southeast Asia that started to enter the Indonesian market in 2013. It has been struggling to maintain its monthly active user (MAU) during the past few months and wishes to get back on its feet as soon as possible. The problem occurred when it was unable to reach its MAU target which is 92 million in 2017. According to the control chart, it hasn't quite made a significant improvement since the beginning of 2017. It is also incapable to meet the target. Several projects have been done just as usual to increase the number of MAU, but nothing happens. The number of MAU is going up and down without ever reaching the target. Based on 5 Whys Analysis, the root cause of the problem lies in two factors, the projects are held too often, and the company cannot specialize in each project based on specific target market criteria. The possible solution to implement is that the company should appoint someone to be the project planning coordinator. He or she will manage all executed projects so that they will align together to support company's mission. Hence, increase the number of MAU as well. In conclusion, this study is aimed to improve the number of Monthly Active Users. This study will use Six Sigma approach to analyze deeply the problem being faced and come up with proposal solution for ABC App to implement in order to increase MAU. This study uses DMAIC method because the method is suitable to improve existing processes. The control phase will also be implemented by using FMEA Table. FMEA Table helps project planning coordinator to control each project so that further risks can be prevented in the beginning.
\end{abstract}

Keywords: Performance, Business Development, Six Sigma, DMAIC

\section{Introduction}

Six Sigma can be defined in various ways (Park, 2003). Tomkins (1997) defines Six Sigma as a program that aims to eliminate almost all defects from every product, process, and transaction. Schroeder (2006) defines Six Sigma as a strategic initiative to drive profitability, increase market share and improve customer satisfaction through the use of statistical tools. Six Sigma is a highly process that helps us focus on developing and delivering near-perfect products and services. It is believed that if you can measure how many defects you have in a process, you can systematically figure out how to eliminate them and get as close to zero defects as possible. If your current sigma level is 4 or even lower depend on your Defect per Million Opportunity, you can work your way up to six sigma by reducing the number of defects. It might take some time, but it has a big advantage in reducing the Cost of Poor Quality by as much as $50 \%$ and more.

Six sigma process is one in which $99.99966 \%$ of the products manufactured are statistically expected to be free of defects ( 3.4 defects per million). The term "six sigma process" comes from the notion that if one has six standard deviations between the process mean and the nearest specification limit, practically no items will fail to meet specifications. This is based on the calculation method

\footnotetext{
* Corresponding author at Jl. Ganesa No.10, Lb. Siliwangi, Kecamatan Coblong, Kota Bandung, Jawa Barat 40132. Email: sulistiaf@students.itb.ac.id
} 
employed in process capability studies. Six Sigma seeks to improve the quality of process outputs by identifying and removing the causes of defects (errors) and minimizing variability in the work process. Data and statistical analysis are used to identify defects in processes and reduce variation.

The use of Six Sigma focuses on outputs that are critical to customers. A defect is defined as anything which could lead to customer dissatisfaction. Six sigma strategy places a clear focus on achieving measurable and quantifiable financial returns to the bottom- $\mathrm{ABC}$ of an organization.

\section{Method}

In traditional form, the measurement of Six Sigma focused on the number of defects per million opportunities (DPMO), which is used to calculate the six sigma metric.

The actual formula is:

$$
D P M O=\frac{(\text { Number of Defects } X 1,000,000)}{((\text { Number of Defect Opportunities per Unit }) \times \text { Number of Units })}
$$

This is because Six Sigma in recent years of its introduction only focused on quantified analysis which usually generated from rejected products. Today, they are not desirable in some situations since Six Sigma has been used widely in other fields as well, particularly in human-intensive processes such as marketing and human resources. Six Sigma methodology began popping up at various business and quality conferences. The basic ingredients are there: processes, customers, suppliers, people, ideas, technical expertise, and commitment to quality. Six sigma can be championed at middle-management levels if we chose to take Six Sigma to a more personal level (Przekop, 2006).

Six sigma is a process of asking questions that lead to tangible, quantifiable answers that ultimately produce profitable results. Six sigma will go deep inside the issue because persistent problems never go away until the root cause is found and corrected. The focus of the Six Sigma program is to reduce the variability of the most important quality characteristics of a product until it reaches the level of variability very small (Montgomery, 2009). Motorola Six Sigma concept aims to reduce the variability in the process so that the specification limits at least within six standard deviations from the average (Montgomery, 2009).

\section{DMAIC Cycle}

Figure 1. DMAIC Cycle

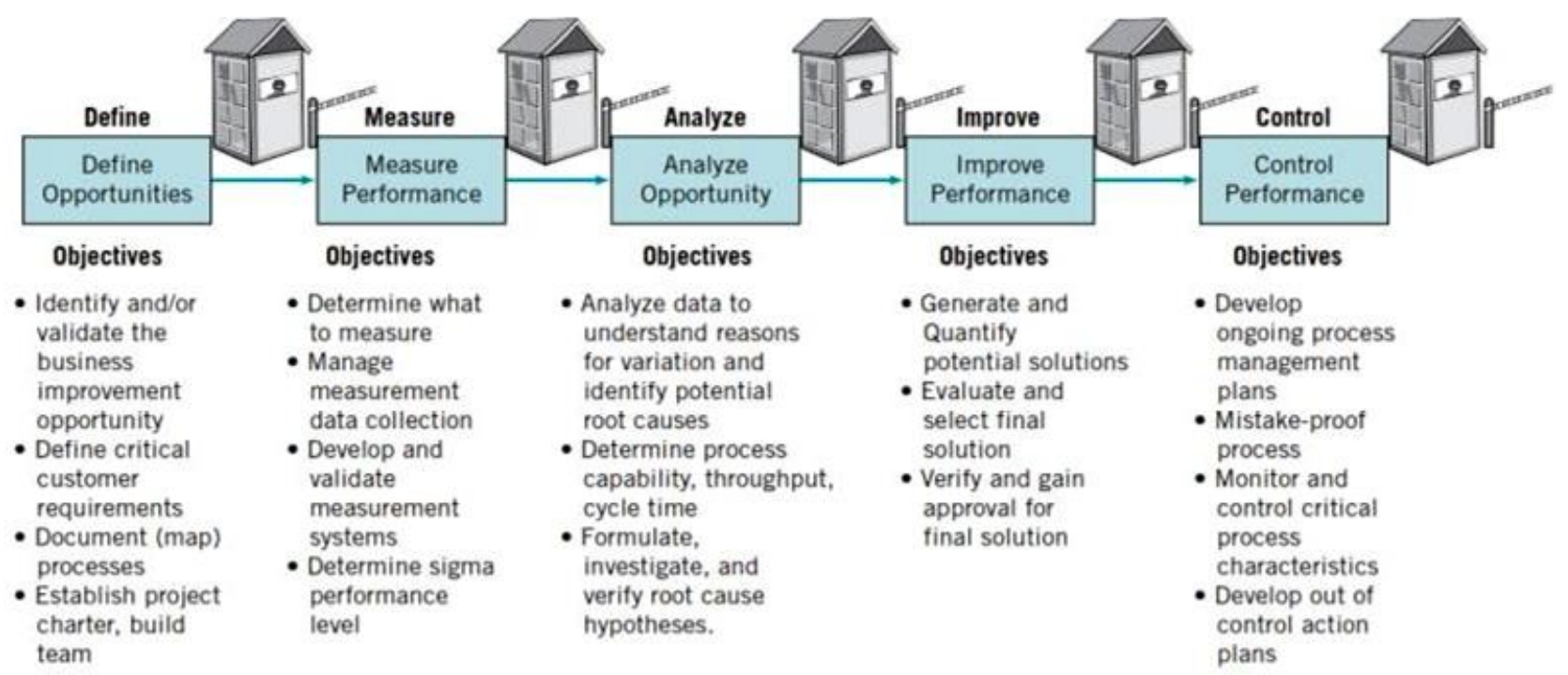




\section{Define (D)}

According to Pyzdek (2003), the define phase determined the goal of improvement activities. At the project level, the goal may be a decrease in the level of defective products or increase productivity in certain processes. These objectives should be obtained from the results of direct communication with customers, stakeholders, and employees. At this stage, the tools used are project charter and process mapping.

\section{Measure (M)}

According to Pyzdek (2003), the measure phase measures the actual conditions of the system. The thing to do is to build a metric that is valid and reliable to observe the progress of the project towards the goals set in the define phase. In this research, the performance measurement process will be reviewed from the aspect of SPC and process capability. SPC was conducted to determine the level of variability of the performance at a certain time. While the capability is performed to determine how the level of variability in the process of delivering a project against established specifications.

Analyze (A)

According to Pyzdek (2003), the analyze phase, carried out an analysis of the system to identify ways to eliminate the gap between the performance of the system or the current process to the desired destination. Preferably used are descriptive data analysis and investigation to assist in the process of understanding the data. The tool that is used at this phase is 5 Why Analysis. 5 Whys Analysis is a great six sigma tool that does not involve data segmentation, hypothesis testing, regression or other advanced statistical tools, and in many cases can be completed without a data collection plan. By repeatedly asking the question "Why", layers of symptoms can be peeled away which can lead to the root cause of the problem.

Improve (I)

Pyzdek (2003), on the improve phase, conducted a search for new ways creative to make things better, cheaper or faster. At this stage, there will be solutions for problems, and other management planning tools to implement this new approach.

Control $(C)$

According to Pyzdek (2003), the control phase carried out control of the new system. This is done to institutionalize the system which has been improved through modifications to the compensation and incentive systems, policies, procedures, MRP, budgets, operating instructions and other management systems. This control phase uses FMEA Table to determine which process should be controlled, how the priority is among each process, and who they are assigned to.

\section{Analysis}

Define (D)

\section{Business Case}

ABCApp currently encounters an issue related to their declining MAU. Their current MAU at the moment is $89,979,059$ users which show 3.675 sigma level. They want to reach six sigma level which means there can only be three hundred defects out of 92 million targets of monthly active users.

\author{
Project Scope \\ 1. Engaging users through internal content: \\ Content Planning: \\ - Start: Identify Issue \\ - Stop: Idea Presentation \\ Content Execution: \\ - Start: Technical Preparation \\ - Stop: On-Going Deliverables \\ Control \& Evaluation: \\ - Start: Collecting Result Data \\ - Stop: Conclusion for further step \\ 2. The project with partners: \\ Content Planning: \\ - Start: Identify Issue \\ - Stop: Idea Presentation \\ Partner Pitching: \\ - Start: Approach Partner \\ - Stop: Transaction Process \\ Content Execution: \\ - Start: Technical Preparation
}




\section{Opportunity/Problem Statement}

Current performance level in sigma measurement: 3.675

Key Performance Indicator:

1) Monthly Active User

Critical to Quality Factor:

1) User engagement

2) Financially sustainable

Critical to Success Factor:

1) Top management commitment

2) Customer focus

3) Clear performance metrics

4) Attaching success to financial benefits

\section{Stop: On-Going Deliverables \\ Control \& Evaluation: \\ - Start: Collecting Result Data \\ - Stop: Conclusion for further step \\ Goal Statement \\ Increase sigma level to 6 \\ Project Plan:}

Table 1

\begin{tabular}{|c|c|c|c|c|c|c|c|c|c|c|}
\hline Week & 1 & 2 & 3 & 4 & 5 & 6 & 7 & 8 & 9 & 10 \\
\hline Meet Manageme & & & & & & & & & & \\
\hline Full Briefing & & & & & & & & & & \\
\hline Decide the Proje & & & & & & & & & & \\
\hline Finalize Charter & & & & & & & & & & \\
\hline $\begin{array}{l}\text { Develop Researc } \\
\text { Plan }\end{array}$ & & & & & & & & & & \\
\hline Conduct Intervie & & & & & & & & & & \\
\hline Gather Data & & & & & & & & & & \\
\hline Analyze Data & & & & & & & & & & \\
\hline Select Solution & & & & & & & & & & \\
\hline $\begin{array}{l}\text { Develop Plan to } \\
\text { Implement }\end{array}$ & & & & & & & & & & \\
\hline
\end{tabular}

Based on the project charter above, the core issue of $\mathrm{ABC}$ App that it is facing right now is the decreasing MAU which is a big problem in the social media world. Hence, ABC Research team (including the author) has conducted preliminary research on why users don't use ABC as much anymore. The result is as following:

$\mathrm{ABC}$ App has conducted research in ten cities targeting three segments of users between the age of 15 to 25 years old. The categories of respondents are high school students, college students, and first jobbers with Monthly Household Expenditure from 1.75 million rupiahs to 4 million rupiahs (B and C economical class). The research was conducted to directly record the voice of users in terms of what they wish to get from an instant messaging app and what they think about ABC in general. The result is as following:

1. ABC is considered trendy, but trendy is not necessarily important.

2. Quota and data are very important, and the ABC app is taking so much space.

3. Stickers are not really attractive since WhatsApp also has emoji.

4. WhatsApp is more widely used because lots of people are already in WhatsApp.

5. WhatsApp has better quality in terms of signal for voice call and video call.

6. They don't like to use voice call and video call because it often gets disconnected because of a bad signal.

7. They like promotional programs like Alfamart and Starbucks.

8. They like ABC Today but they don't find it very trustworthy.

9. People around them are WhatsApp users so they use WhatsApp as well.

10. The reason for choosing IM app is the features, the promotions, and the app that people around them are using.

Customer's VOC above would help ABC App and business development division understand what customers want better. It doesn't specifically state why MAU number is decreasing but it defines customer's preferences which would be helpful to decide the next step on how to increase MAU number. Below is ABC's target for MAU and its defect that impacts its current sigma level: 
Table 2. ABC's target for MAU

\begin{tabular}{ccccc}
\hline 2017 & ABC's MAU & KPI & DEFECT & SIGMA LEVEL \\
\hline Jan & $90,946,242$ & $92,000,000$ & $1,053,758$ & 3.77 \\
Feb & $89,842,953$ & $92,000,000$ & $2,157,047$ & 3.49 \\
Mar & $91,814,539$ & $92,000,000$ & 185,461 & 4.38 \\
April & $89,538,751$ & $92,000,000$ & $2,461,249$ & 3.43 \\
May & $89,750,484$ & $92,000,000$ & $2,249,516$ & 3.47 \\
June & $89,979,059$ & $92,000,000$ & $2,020,941$ & 3.51 \\
Average & $90,312,004$ & $92,000,000$ & $1,687,996$ & 3.675 \\
\hline
\end{tabular}

KPI for MAU was set by ABC plus Corporation

Standard Deviation for Sigma Level: 0.366

Figure 2. Distribution Plot

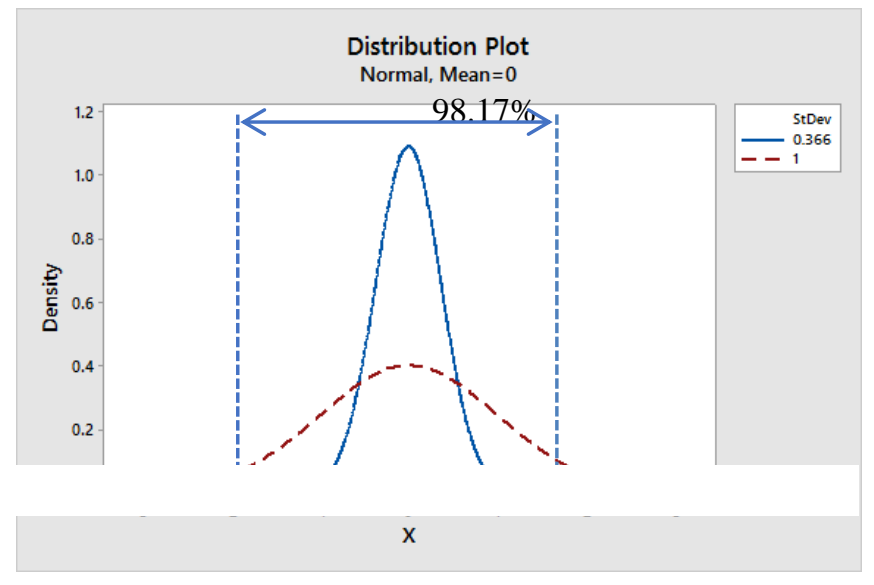

Since the business development division has to conduct two projects in the end, the process mapping for both tasks are as following:

Figure 3. Process Mapping

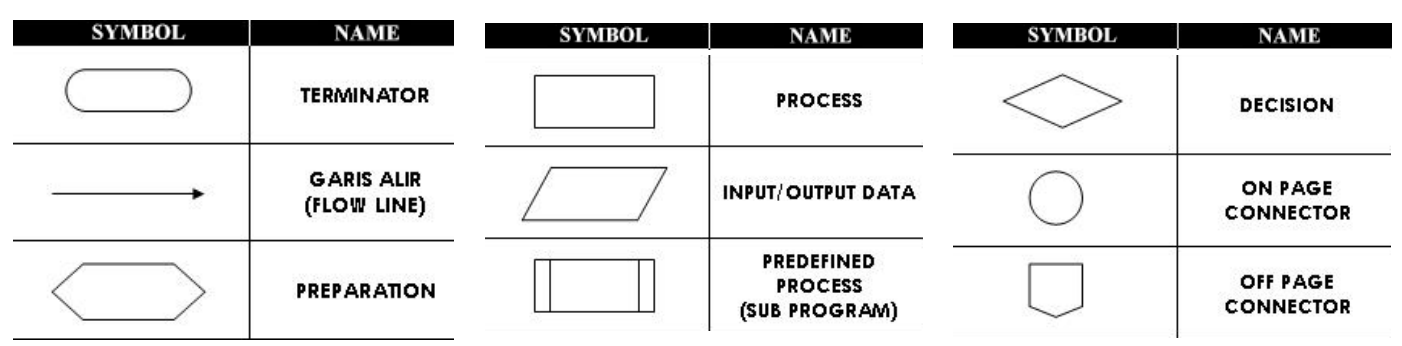


1. Engage Users through Internal Content

Figure 4

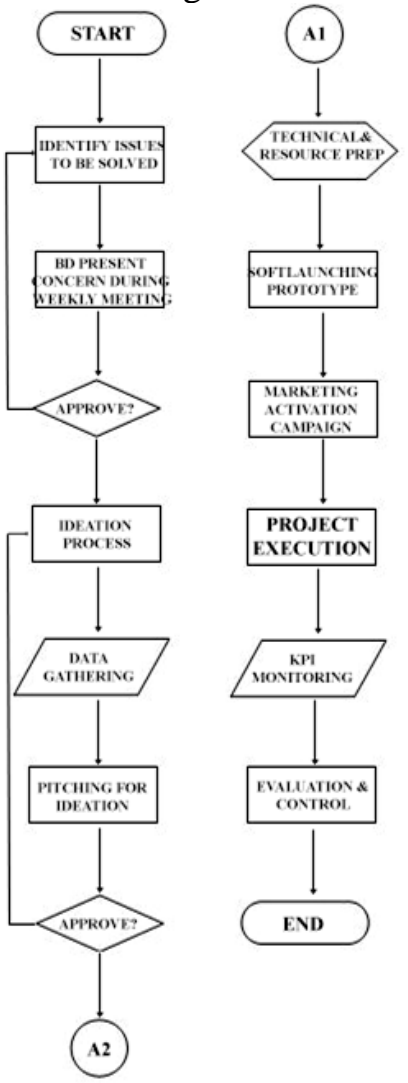

2. The project with Partner for External Content

Figure 5
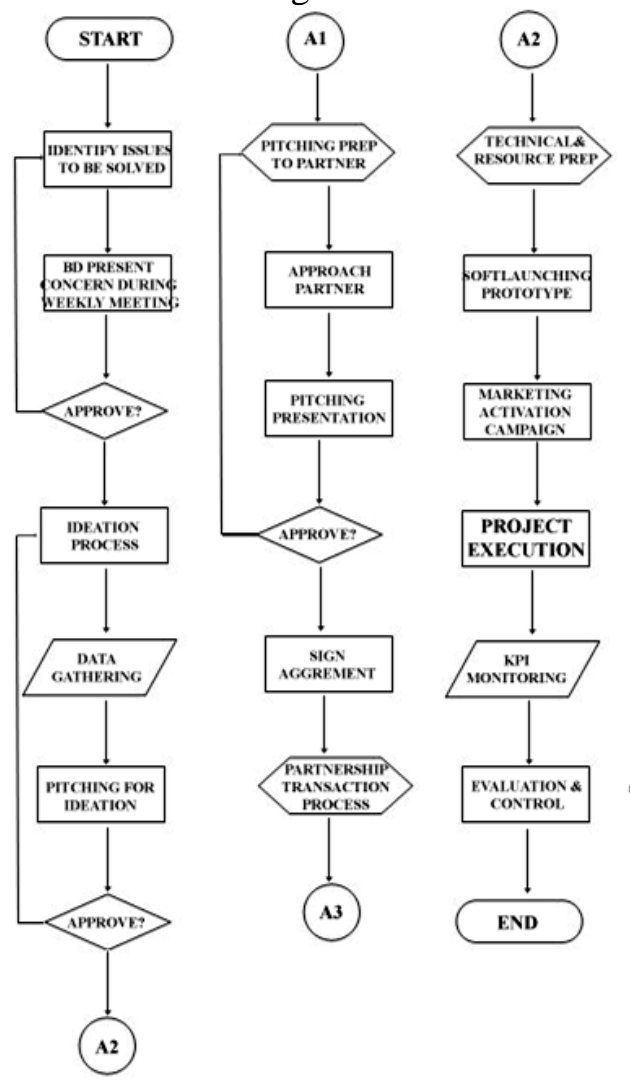

Additionally, Business Development division also has to make sure that the project from each task is financially sustainable for the better growth of the company.

Measure (M)

In the measure phase, the author uses SPC to see stability and process capability. The purpose of this stage is to give an overview of the actual process conditions of the company today.

Table 3. Actual Process Condition of the Company on ABC's MAU

\begin{tabular}{|c|c|c|c|c|c|}
\hline 2017 & ABC's MAU & KPI & DEFECT & $\begin{array}{l}\text { INTERNAL } \\
\text { PROJECTS }\end{array}$ & $\begin{array}{l}\text { EXTERNAL } \\
\text { PROJECTS }\end{array}$ \\
\hline Jan & $90,946,242$ & $92,000,000$ & $1,053,758$ & $\begin{array}{l}\text { Pilkada LIVE } \\
\text { Stream }\end{array}$ & $\begin{array}{l}\text { Lucky Chance with } \\
\text { Matahari Mall }\end{array}$ \\
\hline $\mathrm{Feb}$ & $89,842,953$ & $92,000,000$ & $2,157,047$ & Valentine's Day & Alfamart Mie Sedaap \\
\hline Mar & $91,814,539$ & $92,000,000$ & 185,461 & TGIF & Alfamart BPJS \\
\hline April & $89,538,751$ & $92,000,000$ & $2,461,249$ & Lucky Price & - \\
\hline May & $89,750,484$ & $92,000,000$ & $2,249,516$ & - & OPPO Call Contest \\
\hline June & $89,979,059$ & $92,000,000$ & $2,020,941$ & ABC Ramadhan & AlfamartTurunGunung \\
\hline
\end{tabular}

I-MR Chart is used to measure the result of every process that has been done in 2017. Those processes are in forms of projects held by the Business Development division to increase the number of MAU and maintain other indicator numbers. 
Figure 6. I-MR Chart

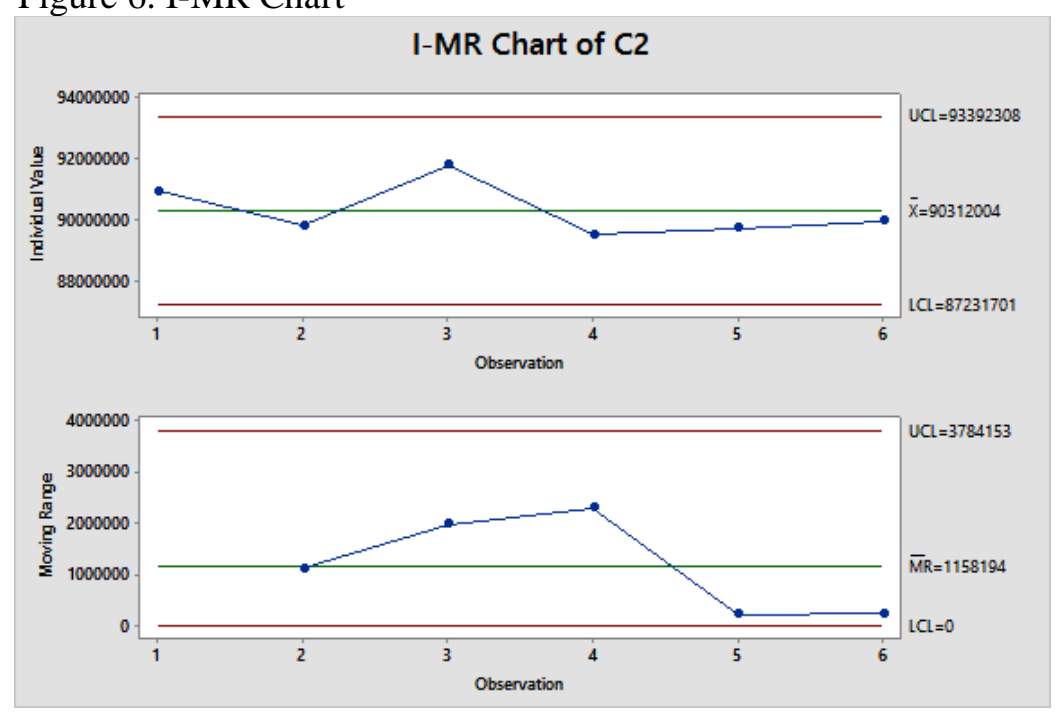

From figure 6, I-MR chart has shown that the individual value hasn't quite reached the KPI. Even though they are still in control, there isn't any progress that showed significant improvement in terms of MAU numbers. This is worrying since it has been the middle of the year but there is not one month that has passed the KPI. Hence, immediate action must be taken.

Another way to report process capability and process performance is through the statistical measurements of $C_{p}$ and $C_{p k}$. Here is the result generated from Excel in the figure below.

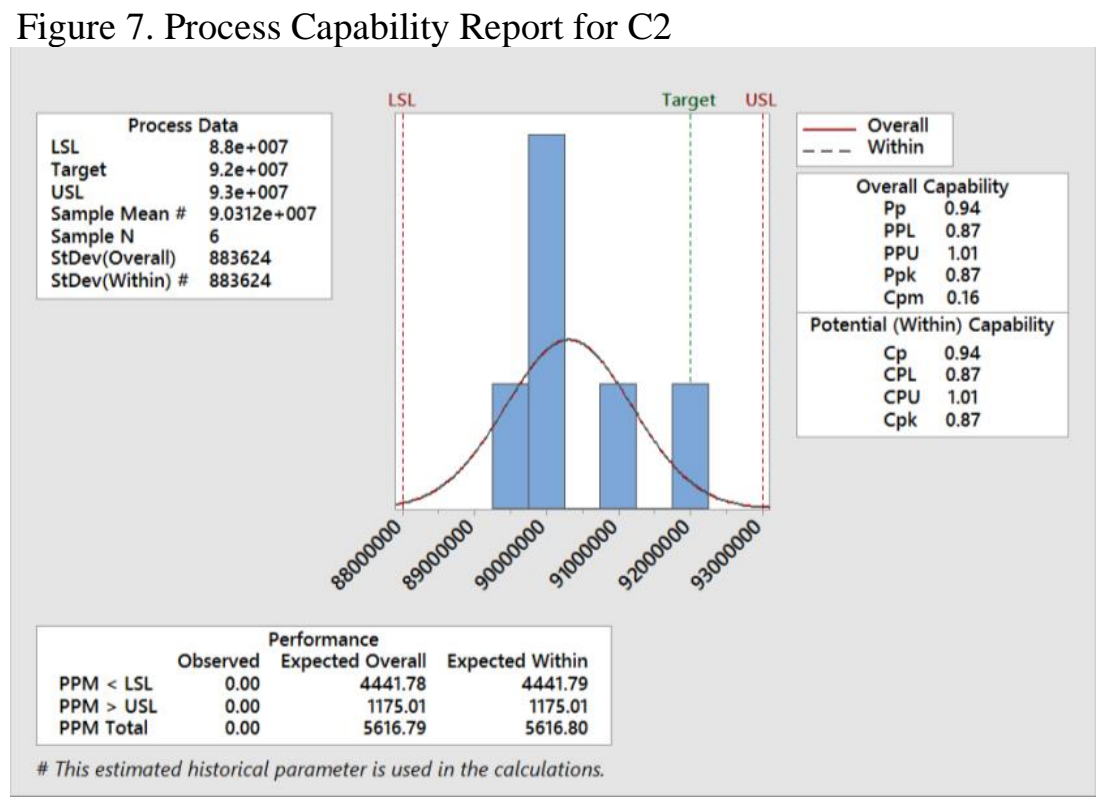

From figure 7, it can be seen that the number of $\mathrm{Cp}$ is 0.94 and $\mathrm{Cpk}$ is 0.87 , which shows that the process is actually incapable of meeting the target. The standard value of $\mathrm{Cp}$ and $\mathrm{Cpk}$ is 1.00 and 1.33 in order to be capable to reach KPI and satisfy customers. With that result, some processes need to be evaluated whether they need to be fixed or the target has to be changed to make it lower. Since changing the target wouldn't be a good solution for company's growth, author will still keep in mind to fix the problem. Hence, in conclusion from the measured phase, the process needs some improvement in order to fix the problem and reach the target.

Analyze (A)

Based on the results in the process define and measure, the main concern is in the number of MAU and it hasn't reached the target for six months. Therefore, immediate action has to be made and the real problem has to be figured out first. The appropriate method used to analyze the root cause that caused 
the problem is 5 Whys Analysis because 5 Whys Analysis gets deep into questioning and digging the problem until the real root cause comes up. 5 Whys Analysis also focuses on one big issue only, instead of being spread into several small issues leading to one big issue. Therefore, all causes were tied up connected to resulting one big problem that has caused decreased performance of the company.

Below is the 5 Whys Analysis for the problem of decreasing MAU:

Table 3. The WHYs analysis

WHY does ABC App experience decreasing MAU (1)?

A: ABC App has been doing the same continues activities (project scope) for the last four years and since 2017, (2) it doesn't generate desirable results anymore.

Q: Why doesn't it generate desirable results anymore?

A: (3) Users say that the projects are not interesting anymore.

Q: Why is the project not interesting?

A: (4) The projects don't give them an incentive or added value.

Q: Why do the projects not give them added value?

A: (5) The projects are given to the wrong target market.

Q: Why are the projects given to the wrong target market?

A: (6) The projects cannot be applied to specific target market only.

Q: Why cannot the projects apply to specific target market?

A: (7) The App doesn't allow any personal information taken from users.

Q: Why else do the projects not give them added value?

A: (8) There is no moment to support the project execution.

Q: Why isn't there any moment to support the project?

A: (9) The project is executed without careful time-framing.

Q: Why is it not executed with careful time-framing?

A: I have no idea.

Q: Why else is the project not interesting anymore?

A: (10) The projects don't become a trend anymore.

Q: Why don't they become a trend anymore?

A: The projects have been done continuously for the past four years.

Q: Why have the projects been done continuously for so long?

A: I have no idea.

Q: Why else is the project not interesting anymore?

A: (11) Users find it annoying.

Q: Why do they find it annoying?

A: The projects are held too often and taking too much mobile data.

Q: Why are they held too often?

A: Too many partners want to hold it.

Q: Why do many partners want to hold it?

A: The projects create engagement between partners and users.

Q: Why does it create engagement?

A: Users react to the project.

Q: Why do they react to the project?

A: They find the projects interesting, useful, and has added value to them.

Q: Why else do they find the projects not interesting?

A: (12) Users prefer basic apps with high quality.

Q: Why do they prefer basic apps with high quality?

A: It is easier to operate and many more people can use it.

From 5 Whys Analysis above it can be concluded that there is twelve Undesirable Effect (UDE) that have happened along the way other than the main problem that has been the biggest issue of the research. Since there is more than one symptom causing the same effect, author then continued the analysis by summing up the result of the analysis into CRT (Current Reality Tree) diagram. CRT diagram is a diagram that links underlying cause to symptoms via cause-and-effect arrows. The CRT 
diagram includes the bold listed UDE above and connects them via cause-and-effect arrows. Hereby is the CRT diagram from 5 Whys Analysis above:

Figure 8. CRT Diagram

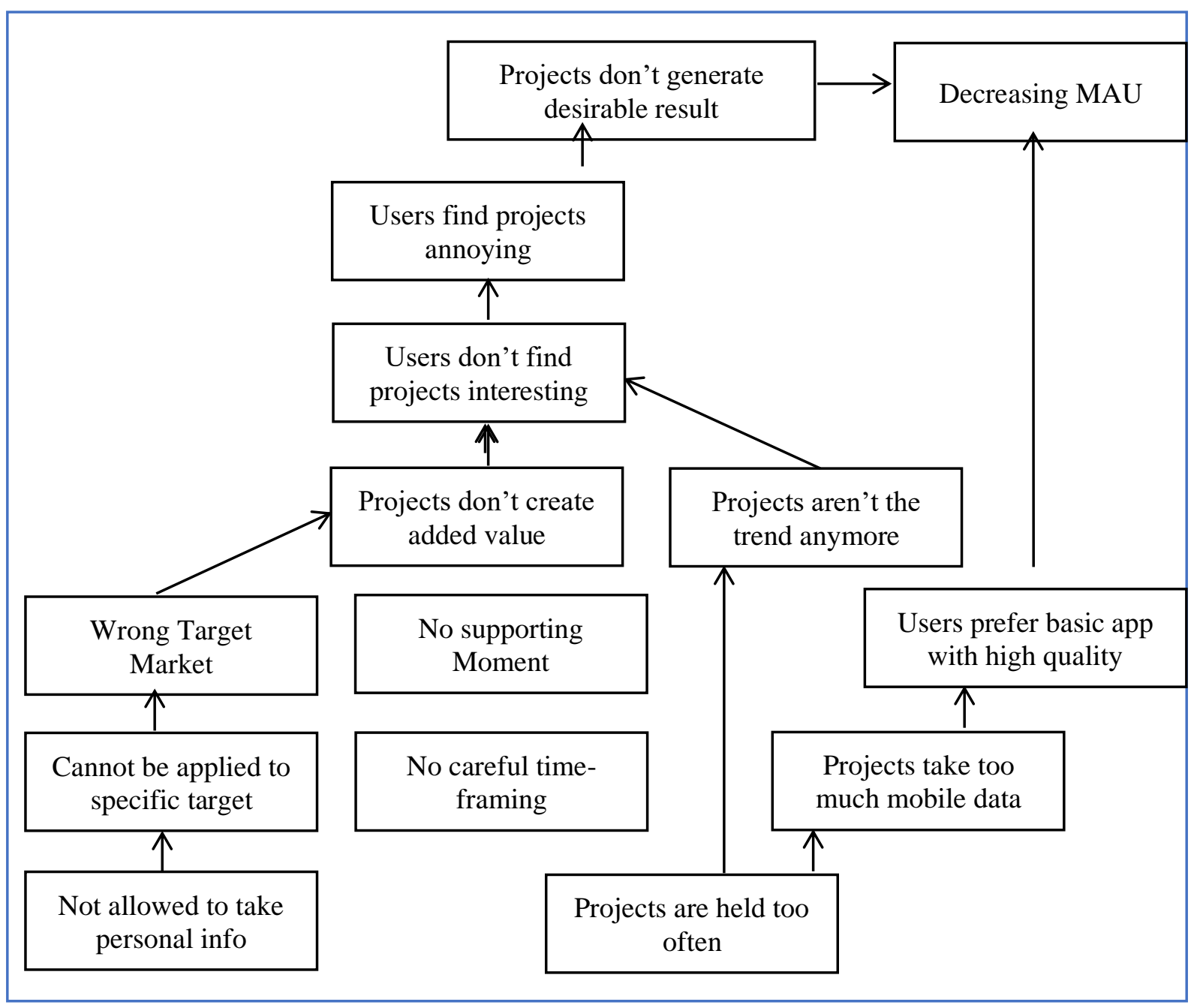

In conclusion, there are two root causes according to the CRT diagram. They are (1) the projects are held too often and (2) the app doesn't allow any personal information taken. Hence, these two root causes are the ones that need to be solved in the next improve step.

Improve (I)

At this stage, there will be explanation about alternative solutions to solve the primary causes that have been determined in the previous stage. The primary causes that have been determined are the two root causes that have been found in Figure 8. This improves phase will show how management can have solution from the primary cause and solve the problem defined.

- Project Planning Coordinator

Appointing a project planning coordinator could really manage the whole thing to be put together. So far, there hasn't been anyone that is appointed to do this. Each project is just proposed to the business development director and managing director, and if the idea and the budget are approved, the project is good to go. No one is really paying attention to whether the project aligns with the company's vision or not, whether it helps the company to reach its aspiration, or whether it goes hand-in-hand with each other. Each staff just focuses on executing their duties without thinking about the big picture. This is actually understandable because thinking about the big picture will require a lot of attention. This also cannot be put on business development director or the managing director because they have enough to 
think about. Therefore, appointing someone as the project planning coordinator is the most feasible solution to be implemented.

The project planning coordinator will have several job descriptions as followed:

1. Determine the stages that should be taken quarterly in order to achieve the company's vision

2. Hold a meeting with each head division to socialize the stages and how it is going to be executed

3. Manage how each project can contribute to achieving each stage's KPI

4. Make sure that all projects go in line with each other in terms of their value, objective, timing, and target market

5. Optimize the division that hasn't been featured enough

6. Evaluate the result of each project in terms of its contribution to achieving the company's vision

7. Be the core coordinator to maintain each project's result

The project planning coordinator should focus more on the company's vision instead of just increasing the number of MAU. Theoretically, both of them are the same thing, but company's vision doesn't only include the number of MAU. It also includes bringing the right company's branding in the eye of customer as well as making sure that the company's focus is on the right path. In conclusion, project planning coordinator cannot only focus on the quantitative target but on the qualitative target as well. In terms of hierarchical order, project planning coordinator should work independently on the side of other head divisions but below the division's directors and the managing director.

Control (C)

The control phase is implemented because there are some foreseeable risks that might come up in the future that could cause the problem to come up again even though the improvement phase has been done. Therefore, author conducted FMEA Table to measure several foreseeable risks and assign responsible people to solve the problem if something came up in the middle of the project execution. The FMEA Table is as followed:

Table 4. FMEA Table

\begin{tabular}{|c|c|c|c|c|c|c|c|c|}
\hline $\begin{array}{l}\text { Process Mapping } \\
\text { Stages }\end{array}$ & $\begin{array}{l}\text { g Potential } \\
\text { Failure Mode }\end{array}$ & $\begin{array}{l}\text { Potential } \\
\text { Effect of } \\
\text { Failure }\end{array}$ & Severity & Occur & r Detect & RPN & Responsibility & Process Control \\
\hline $\begin{array}{l}\text { Identify needs to } \\
\text { be solved }\end{array}$ & $\begin{array}{l}\text { Too late to } \\
\text { solve the issue }\end{array}$ & $\begin{array}{l}\text { Project isn't } \\
\text { implemented } \\
\text { effectively }\end{array}$ & 4 & 4 & 3 & 48 & $\begin{array}{l}\text { Business } \\
\text { development }\end{array}$ & $\begin{array}{l}\text { The issue must } \\
\text { happen at most two } \\
\text { weeks before the } \\
\text { weekly meeting }\end{array}$ \\
\hline Ideation Process & $\begin{array}{l}\text { The creativity } \\
\text { isn't good } \\
\text { enough }\end{array}$ & $\begin{array}{l}\text { KPI wouldn't } \\
\text { be achieved }\end{array}$ & 4 & 3 & 3 & 36 & $\begin{array}{l}\text { Business } \\
\text { development }\end{array}$ & $\begin{array}{l}\text { Include at least one } \\
\text { success story with } \\
\text { clear KPI }\end{array}$ \\
\hline $\begin{array}{l}\text { Technical and } \\
\text { Resource } \\
\text { Preparation }\end{array}$ & $\begin{array}{l}\text { Something is } \\
\text { forgotten to be } \\
\text { prepared }\end{array}$ & $\begin{array}{l}\text { Execution is } \\
\text { hampered }\end{array}$ & 3 & 4 & 4 & 48 & $\begin{array}{l}\text { Admin and } \\
\text { Design Team }\end{array}$ & $\begin{array}{l}\text { Provide at least } 1 \\
\text { month for technical } \\
\text { and resource } \\
\text { preparation }\end{array}$ \\
\hline $\begin{array}{l}\text { Soft launching } \\
\text { prototype }\end{array}$ & $\begin{array}{l}\text { Launching isn't } \\
\text { done correctly }\end{array}$ & $\begin{array}{l}\text { The result } \\
\text { gained isn't } \\
\text { reliable }\end{array}$ & 4 & 4 & 4 & 64 & $\begin{array}{l}\text { Business } \\
\text { development }\end{array}$ & $\begin{array}{l}\text { Use reliability and } \\
\text { validity test after the } \\
\text { result is gained }\end{array}$ \\
\hline $\begin{array}{l}\text { Transaction } \\
\text { Process with } \\
\text { Partner }\end{array}$ & $\begin{array}{l}\text { Something } \\
\text { missing from } \\
\text { the agreement }\end{array}$ & $\begin{array}{l}\text { Execution } \\
\text { isn't effective }\end{array}$ & & 1 & 1 & 4 & Legal Team & $\begin{array}{l}\text { Conduct at least one } \\
\text { meeting to discuss } \\
\text { the agreement }\end{array}$ \\
\hline
\end{tabular}


Table 5. Severity, Occurrence, and Detect

\begin{tabular}{cccc}
\hline Scale & Severity & Occurrence & Detect \\
\hline 1 & $\begin{array}{c}\text { No significant impact } \\
\text { Only impact one } \\
\text { division }\end{array}$ & $\begin{array}{c}\text { Never happen before } \\
\text { Has happened once }\end{array}$ & $\begin{array}{c}\text { Always being monitored } \\
\text { Weekly evaluation }\end{array}$ \\
3 & $\begin{array}{c}\text { Impact several divisions } \\
\text { Has happened more than once } \\
\text { but not often }\end{array}$ & $\begin{array}{c}\text { Monitored only during } \\
\text { evaluation meeting } \\
\text { Happen often }\end{array}$ & $\begin{array}{c}\text { Unmitored but has some } \\
\text { sort of record }\end{array}$ \\
4 & $\begin{array}{c}\text { Impact the whole } \\
\text { company internally } \\
\text { Break trust from a lot of } \\
\text { parties }\end{array}$ & Always happen & $\begin{array}{c}\text { Almost impossible to detect } \\
\text { beforehand }\end{array}$ \\
\hline
\end{tabular}

FMEA Table is made based on each step in the process mapping because even though there is already a project planning coordinator involved, the executor of the project still cannot put their hands off the project itself. They still need to be careful and pay attention to detail to make sure that the project can be executed well. In the end, the result of the projects will still be the determination of whether the target is achieved or not. This FMEA Table can also prevent the problem from being too late to be taken care of and generate even worse problems. Once an action has been taken, the responsible person should fill in table 6 above and give it to project planning coordinator.

This FMEA Table is basically a tool for project planning coordinator to control each project without being too disruptive. In theory, project planning coordinator needs to make sure whether the project is executed properly or not. She cannot hold meeting to monitor each step in the process mapping because it will take too much time and it will only delay the process. Hence, this FMEA Table will be the guidance for the project planning coordinator to communicate with each division about the progress of each step in the process mapping. Hence, they don't need to waste too much time holding a meeting, but they can still coordinate with each other.

\section{Conclusion}

In conclusion, $\mathrm{ABC}$ App currently is still at 3.675 sigma level on its performance level based on its MAU number target. This is the biggest issue that the company is currently facing since the MAU number keeps decreasing in 2017 which could result in worse problems in the future. The measurement phase also shows that the process is still incapable to meet the target that is set by the company. The progress is still stagnant so far and not showing any significant improvement.

From the analysis, it is generated that the root cause of the problem is that the projects are held too often. Hence, the solution for this is to assign one person as project planning coordinator to manage all projects executed by the company. The project planning coordinator will have its own job description separately from all other divisions. He or she has to monitor every project and make sure that all projects are on the right path so that the company's target can be achieved at the end.

In order to monitor each project, project planning coordinator has come up with FMEA Table to make sure that all process mapping steps to execute the projects are controllable. It wouldn't make any impact if each project has been aligned perfectly but is not very well executed. This FMEA Table is highly necessary to reduce risk as little as possible in the future. Since project planning coordinator will not be able to monitor each project closely, this FMEA Table will do the job.

\section{Further Research}

Further research involves the steps that felt necessary but haven't been done due to the author's limitation and situational limitation. Some of the things that need to be considered as further research are: (1) How impactful it is to allow the company to collect the user's personal information ( 2 nd root cause) to increase the number of MAU; (2) How effective the work of project planning coordinator in terms of its coordination with other divisions to achieve the target is set; (3) Quantitative analysis on how to measure each project's contribution to the target of MAU. Those three are the points that haven't been included in the analysis, but the author feels that all of those are necessary in order to develop the analysis to be even further. Further research with all three being 
implemented will result in a much better conclusion and more thorough result of the research. Hence, it'd increase the possibility of the recommendation to achieve the target.

\section{References}

Montgomery, D.C. (2009), Statistical Quality Control: A Modern Introduction, 7th ed., John Wiley \& Sons, Hoboken. Park, S.H. (2003), Six Sigma for Quality and Productivity Promotion, Asian Productivity Organization, Tokyo.

Przekop, P. (2006), Six Sigma for Business Excellence, McGraw-Hill International Edition, New York.

Pyzdek, T. (2003), The Six Sigma Handbook: A Complete Guide for Green Belts, Black Belts, and Managers at All Levels, 2nd ed., McGraw-Hill International Edition, New York.

Schroeder, Richard, Mikel, H. (2006), Six Sigma: The Breakthrough Management Strategy Revolutionizing the World's Top, Random House, Doubleday.

Tomkins, R. (1997), “GE beats expected 13\% rise”, Financial Times, p. 22. 